Danijela Stošić Panić*

\title{
Current State and Impact of Strategic Planning Activities on Entrepreneurs' Financial Performance: Case of Serbia
}

DOI: 10.7595/management.fon.2019.0010

\begin{abstract}
:
Research Question: The study was designed to explore the current state and the importance of strategic planning for entrepreneurs in the Republic of Serbia. Motivation: Recognizing that different levels of sophistication of planning activity exist in small businesses (Bracker \& Pearson, 1986), the positive impact of this managerial activity on entrepreneurial performance (Gibbons \& O'Connor, 2005), as well as the fact that this is an underexplored research field (Parnell, Long \& Lester, 2015), the research was undertaken in order to address these issues in the Serbian context. The paper aims to identify the features of strategic planning performed by Serbian entrepreneurs and the relation of this activity to their financial performance. By exploring the current state of these issues, the paper will point out directions for its improvement. Idea: The research has been conducted with a main goal to explore the characteristics of the strategic planning undertaken by Serbian entrepreneurs and its impact on their financial performance. With an increasing importance of female entrepreneurship and going-on studies examining gender differences across different aspects of managerial behaviour of entrepreneurs, the paper investigates the existence of genderbased differences in strategic planning practice between female and male entrepreneurs in Serbia. Data: A random sample of 327 SMEs' owners and individuals registered as entrepreneurs was drawn out of the Serbian Business Register Agency's database. A questionnaire containing nine-itemed scale for evaluating the features of strategic planning of Serbian entrepreneurs was developed using the online platform Google Docs. One hundred and one entrepreneurs from the sample responded, thus providing the data for further analysis. The data on financial performance of respondents were obtained from their publicly available financial statements. Tools: Several statistical methods were used for testing the proposed hypotheses such as descriptive statistics measures, Cronbach alpha measure of scale's internal consistency, one sample t-test, simple linear regression, Shapiro-Wilk test of normality and nonparametric Mann-Whitney $U$ test. The data were analyzed in SPSS, Version 22. Findings: As it was expected, strategic planning is an underdeveloped activity among Serbian entrepreneurs. But surprisingly, although hypothesized, there were no gender-based differences regarding this aspect of managerial behaviour of entrepreneurs. The study also suggests that strategic planning contributes to financial performance of Serbian entrepreneurs. The results obtained on Serbian sample are comparable with others presented in relevant literature and obtained in other contexts. By tackling these issues, the paper reveals some areas of the strategic management academic courses and training programmes for entrepreneurs that should be emphasized in order that the competitiveness of the small business sector should be improved. Contribution: This paper contributes to both the strategic management and entrepreneurship literature, thus filling the research gap that exists regarding the strategic management practice in small businesses.
\end{abstract}

Keywords: strategic planning, entrepreneurship, SMEs, financial performance, gender

JEL Classification: L26, J16, L25, M19

\section{Introduction}

As an initial phase of the management process, planning is a complex managerial activity focused on building forces and developing strategic capabilities for establishing and improving competitive advantage (Lerner \& Almor, 2002, p. 112). Strategic planning is an activity of defining long-term goals, developing courses of 
action and allocating the resources for their achievement (Wang, Walker, \& Redmond, 2007). In a word, the strategic planning process deals with both ends (or goals) and means (Dibrell, Craig, \& Neubaum, 2014) which are related to the firm's competitive advantage. By enabling flexibility to external changes and reducing the uncertainty, roles that are becoming increasingly important in the rapidly changing environment (McKiernan \& Morris, 1994), strategic planning contributes to the business efficiency and allows firms to outperform their competitors.

Although competitive advantage may be more critical for small businesses and entrepreneurs (Davis \& Olson, 2008), their behaviuor tends to be unplanned, informal, reactive or opportunistic (Hagen, Zucchella, Cerchiello, \& De Giovanni, 2012). Various reasons are identified that explain the absence or inadequate strategic planning in the small business sector. Scarcity of human, financial resources and time is, broadly speaking, the main reason for an informal and unstructured strategic planning process performed by entrepreneurs (Davis \& Olson, 2008; Löfving, Säfsten, \& Winroth, 2014; Parnell, Long \& Lester, 2015). At the same time, positive impact of the strategic planning activity on business success is well-documented in the literature (Walker, Wang, \& Redmond, 2007; Donkor, Donkor, \& Kwarteng, 2018). Furthermore, the aim of here presented research is to explore the main features of strategic planning activity of Serbian entrepreneurs and to identify its relations to business performance. A comprehensive literature review provided by Reiche and Reschke (2006) shows that the research on strategic planning in SMEs can be further enriched, while Amonini and Ogunmokun (2015) state that the majority of the research on strategic planning practices is done in the UK and USA and that it refers to large organizations. So, current study may be seen as one of the efforts to fill the aforementioned gaps.

Moreover, since female entrepreneurship is an increasingly significant economic phenomenon, gender differences regarding different variables are being considered. Gender-based differences in various aspects of business behavior are recognized and approach to the strategic management is one of them (Walker et al., 2007). Therefore, an important aspect of the research presented by this paper is the gender-related issues regarding the strategic planning activities of Serbian entrepreneurs. Various issues related to gender of the entrepreneurs are in the focus of both academic researchers and policy makers. Besides the supporting schemes developed for entrepreneurs in general, there is a stream of supporting programmes in Serbia specifically tailored for women entrepreneurs. Therefore, it seems reasonable to investigate whether there are some differences between female and male entrepreneurs regarding their need for support in the domain of building or improving their strategic planning competences.

The remainder of the paper is structured as follows. After presenting the theoretical argumentation and proposing research hypotheses in the second section, the third section of the paper brings the methodological considerations of the study. Results and their discussion are presented within the fourth chapter of the paper, which is then closed with certain concluding remarks.

\section{Theoretical Background and Hypotheses Development}

Planning in small businesses mostly focuses on activities such as environmental analysis, defining objectives, formulating a strategy, projecting financial indicators, measuring performance, and control and correction activities (Bracker \& Pearson, 1986, p. 592). The strategic aspect of planning, as an expression of a proactive approach, is a central management activity which is strongly linked to different performance measures and contributes to the success of small businesses (Lerner \& Almor, 2002). However, it is often concluded that strategic planning is generally underdeveloped in small businesses and that the lack of implementation of this fundamental management practice is one of the key reasons for the high mortality rate of these enterprises (Bracker, Keats \& Pearson, 1988; Karami, 2007). Analyzing 29 research studies, Kraus, Reiche and Recshke (2007) find that results published in these studies suggest that there is a link between the type, degree of formality/intensity, the use of strategic planning instruments and the company size. All these variables are positively correlated with the size of the business.

Empirical studies examining the state and the effects of planning activity most often equalize this managerial activity with the existence of written planning documents (Brinckmann \& Min Kim, 2015). When measured like that, results indicate that the planning activity is not a frequent, consistent, or continuous management activity in small businesses (Gibson \& Cassar, 2005). But not everything is that bad because it is argued that the absence of a formal planning process in small businesses is not caused by the fact that owners-managers do not recognize the significance of such process, because they usually do (Siddique, 2015), but by the lack of time and other resources (Kraus et al., 2007) or knowledge (Klacmer Calopa, 2017). Nevertheless, in equalizing the existence of the formal plans as the outcome with the existence of the plan- 
ning activity as a process, one should be careful. Brinckmann, Dew, Read-Mayer, Haug and Grichnik (2018) argue that the business planning process should be measured or judged upon two dimensions, one that measures the formality, and the other that refers to the substantive planning behaviour. This means that an entrepreneur can be engaged in planning in order to try to shape or control his/her business future, but never to develop a formal written plan. At the same time, an entrepreneur may develop a written plan perhaps just to satisfy some formal institutional obligation, but never to see and to understand the meaning and the importance of this activity. Of course, an entrepreneur may do both or neither of the above mentioned.

Even in situations where it does exist, the planning activity in small businesses is not detailed and rarely does it have a strategic time horizon (Frost, 2003; Kraus et al., 2007). Although one of the most common skills acquired in various entrepreneurial training programmes relates to the preparation of a business plan, empirical evidence shows that business plans of entrepreneurs are usually reduced to the description of tactics and concrete activities (Frost, 2003). These business plans that are burdened by tactics often lack a strategic planning approach. A well-developed and sophisticated strategic planning presumes long-time horizon, objective data inputs and analysis and as such it addresses all functional areas of the business. Although various empirical studies associate the strategic planning with the competitiveness and success of small businesses, Donkor et al. (2018) suggest that a majority of small business owners and entrepreneurs do not recognize the benefits of this management activity for their businesses and that they perceive strategic planning as an activity adequate for large businesses only.

Building on the above, in the present study it is anticipated that:

$\mathrm{H} 1$ : Strategic planning activity is underdeveloped in the management practice of Serbian entrepreneurs.

A business planning activity that has been adequately developed and implemented contributes to the success of small businesses (Bracker et al., 1988; Rue \& Ibrahim, 1998; Lerner \& Almor, 2002; Wijewardena, De Zoysa, Fonseka, \& Perrera, 2004; Allred, Addams, \& Chakrabotry, 2007; Hodges \& Kent, 2007). Allred, Addams and Chakraborty (2007) argue that both formal and informal planning is crucial for the success of small businesses. On the other hand, according to Bracker et al. (1988) and Welter (2003), the performance of small businesses is affected by the level of the complexity of planning, more than by the existence of this activity per se. Different levels of sophistication of the planning activity can be identified depending on whether the manager analyzes external factors, quantifies business goals, defines budgets, prepares written plans, and whether he/she plans a comparison of planned and accomplished, as well as the mechanisms for filling the gaps (Rue \& Ibrahim, 1998; Hodges \& Kent, 2007). Moreover, the degree of planning sophistication can be measured by the level of a detailed approach and scope of the planning activity, its formality and the period it covers (Jorissen, Reheul, Laveren, \& Martens, 2009; Schayek \& Dvir, 2011; Mitchelmore \& Rowley, 2013). Although much emphasis is put on the formal planning process, Dibrell et al. (2014) warn that the formality of the planning process can result in rigidness which is incompatible with modern environmental dynamism. Supporting the previous statement, these authors find that truly competitive are those firms who manage to find an optimal balance between formality and flexibility of the planning process.

Starting from the level of its sophistication, the planning activity in small businesses can be labelled as structured strategic planning, structured operational planning and intuitive planning (Table 1).

Table 1: Levels of sophistication of the planning activity in small businesses

\begin{tabular}{l|l}
\hline Sophistication level & Characteristics \\
\hline $\begin{array}{l}\text { Structured strategic } \\
\text { planning }\end{array}$ & $\begin{array}{l}\text { Formalized activity with written results, which analyzes the external and } \\
\text { internal environment in the time continuum (past, present, future) and } \\
\text { determines the measurable long-term goals. }\end{array}$ \\
\hline $\begin{array}{l}\text { Structured operational } \\
\text { planning }\end{array}$ & $\begin{array}{l}\text { Management activity which defines the budget for the current period, as } \\
\text { well as quantitative goals in the field of production, costs, human } \\
\text { resources, and the like. The direct result of this activity is a written short- } \\
\text { term plan. }\end{array}$ \\
\hline Intuitive planning & $\begin{array}{l}\text { Planning activity with a short time horizon, without written plans as } \\
\text { results, based on experience, intuition and goals of the owner. }\end{array}$ \\
\hline
\end{tabular}

Source: Bracker \& Pearson, 1986, p. 507. 
Strategic planning is important for providing information, scanning the external and internal environment and reducing uncertainty, and by doing this it contributes to business performance (Kraus, Harms \& Schwarz, 2006). Small businesses that implement structured strategic planning are more successful, measured in financial terms (Bracker \& Pearson, 1986; Wang et al., 2007). The basis of the success of these businesses is the entire planning process; not only efficient planning procedures, but also an adequate implementation and control of the plans' execution (Wijewardena et al., 2004; Arasa \& K'Obonyo, 2012; Gomera, Chinyamurindi, \& Mishi, 2018). The results of the meta-analysis of the relationship between planning activities and financial performance even indicate that the positive effects of planning on financial performance are more pronounced in small businesses in comparison with the large-scaled companies (Fossen, Rothstein, \& Korn, 2006). Mitchelmore and Rowley (2013) find that planning in various domains of business contributes to the business performance and that the longer the planning time-span is, the better the performance is. Quoting several studies, Gibbons and O'Connor (2005) conclude that there are various results about the effects of strategic planning on performance, but that evidence does suggest that strategic planning is positively associated with business performance. Similarly, Gomera et al. (2018) find that two most important predictors of entrepreneurial financial performance are the existence of written strategic plans and the length of the planning horizon.

Taking the above into account the following hypothesis is defined:

H2: Strategic planning activity has a positive impact on financial performance of Serbian entrepreneurs.

Different aspects of managerial behavior, such as management style, leadership aspirations, commitment to the organization, and the like, are studied in a gender context (Nir, 1999; Kot, Meyer, \& Broniszewska, 2016). Gender-based differences can be identified throughout the entire management process. Female entrepreneurs prefer to personally perform and monitor daily business activities (Cuba, Denezo, \& Anish, 1983; Hughes, 2005). They tend to hold the control over their businesses in their own hands (Mukhtar, 2002; Lim \& Envick, 2013). Lerner and Almor (2002) claim that strategic planning activities are more likely to occur in firms operating in an uncertain environment, while Bracker et al. (1988) suggest that strategic planning is more likely to be performed by people who have internal locus of control and, thus, believe that determinants of success can be identified, understood, predicted, and controlled. If women tend to have external locus of control as argued by Verheul et al. (2012), and if they are mainly operating in slow-growing, low-profit (Bird \& Sapp, 2004; Kepler \& Shane, 2007; Aidis, 2016; Terjesen, 2016; Braches \& Elliot, 2017; Henry, Orser, Coleman, \& Foss, 2017) and hence less uncertain industries, then it is justifiable to expect that strategic planning will be a feature of their management activities to a much lower extent.

A number of studies suggest that women as entrepreneurs are less concerned with business growth (Fleck, Hegarty, \& Neergaard, 2011; Reichborn-Kjennerud \& Svare, 2014; Ali, 2016). Planning in general is vital for managing business growth (Pasanen, 2003). Moreover, Orser, Hogarth-Scott and Riding (2000) claim that strategic planning is positively linked to the entrepreneur's intention to grow, while Pasanen (2003) cites studies suggesting that fast-growing small firms perform strategic planning on regular basis. When the business goal is to remain small and preserve stability, then strategic planning is a relatively less important management activity. In line with this reasoning are Costin's (2012) findings that a majority of female entrepreneurs prepare informal plans with assistance of friends and family, rather than professional support agencies. Similarly, Mitchelmore \& Rowley (2013) reports that female entrepreneurs have very short planning horizons (even shorter than three months) and that the absence of longer-term planning could seriously affect their business performance and growth.

The planning subject's personal perception of time may determine the dominant time horizon in his/her planning activities (Nir, 1999). So, the reason why female entrepreneurs are less involved in strategic planning can be caused by their shorter time perspective in the realization of activities (ibid.). This and similar reasons may explain the absence of a formal planning process in women-owned businesses and the fact that they generally lack written plans and policies (Cuba et al., 1983; Mukhtar, 2002). Specifically, Yusuf and Saffu (2005) claim that planning is more sophisticated in men-owned and managed small businesses, in terms of formality, implementation of objective tools and techniques, time horizon and thoroughness of the planning activity.

Brinckmann and Min Kim (2015) find that higher entrepreneurial self-efficacy and the existence of the prefounding entrepreneurial experience contribute to the likelihood that an entrepreneur will engage in business planning activities. At the same time, compared to men, women have a lower level of entrepreneurial selfefficacy (Spangoli, Caetano, \& Santos, 2015; Nowinski, Haddoud, Lancaric, Egerova, \& Czegledi, 2019) and they rarely have prior entrepreneurial experience (Stosic Panic, 2017). 
Having in mind the above argumentation, it is hypothesized that:

H3: Strategic planning activity is less developed and implemented by Serbian female entrepreneurs, relative to their male counterparts.

\section{Methodology}

The Serbian Business Register Agency's data base was a frame for randomly drawing the sample of 327 SMEs' owners and individuals registered as entrepreneurs. After receiving completed questionnaires, the research was conducted on a reduced sample of one hundred and one respondents (34 female and 67 male entrepreneurs). The businesses from the sample were $13.93 \pm 11.12$ years old, on average. The gender structure of the sample is comparable with one analyzed by Babovic (2012) (binomial test: $p=0.172,1$ tailed), and by the National Agency for Regional Development (2013) (binomial test: $p=0.464$, 1-tailed). A majority of the sample units (79.21 percent) operate in the service-sector businesses, which is comparable with data at the national level (binomial test: $p=0.139$, 1-tailed).

A scale with nine items was developed to measure the strategic planning activity variable. This nine-itemed scale was defined to measure the time horizon, the content and the level of formality of the business planning activity. A reverse coding of the fifth item ${ }^{2}$ was performed in order to unify the scale measuring the level of development of the strategic planning activity. After doing this, a scale on which a higher score indicates a more developed strategic planning activity was obtained (Cronbach $\alpha=0.750$, without a possibility of improvement). Respondents were asked to rate their level of agreement with each of these nine items on a fivepoint Likert scale (1-strongly disagree, 2-disagree, 3-no opinion, 4-partially agree, 5-totally agree). The overall score indicating the level of development of the strategic planning was calculated as an average value of the scores given to each of the nine items of the scale. The financial performance of Serbian entrepreneurs was judged upon net profits that they had realized.

The central tendency measure coupled with one-sample t-test was used to explore the validity of the first hypothesis. The existence and the nature of the impact of the strategic planning activity on financial performance of Serbian entrepreneurs was assessed by a simple linear regression model. Finally, since the data on strategic planning variable in both gender groups failed to satisfy the assumption about the normality of distribution (Shapiro-Wilk<0.05), the Mann-Whitney $U$ test of differences between these groups was run. The $p$-values are presented for 2-tailed tests, unless otherwise noted.

\section{Results and Discussion}

The scale for measuring the level of development of the strategic planning activity was defined in such a manner that score 3 means that the respondent does not have an opinion about the item, while score 4 indicates that there is a partial agreement with the item. Due to the nature of the scores defined by the scale, the value of 3.51 was chosen to be the threshold value, meaning that mean score higher than 3.51 indicates that the strategic planning activity is, at least partly, performed by an entrepreneur. Of course, the higher the score, the more comprehensively is activity of strategic planning implemented by an entrepreneur.

As it was expected, the strategic planning activity is not part of the managerial process of Serbian entrepreneurs. The average score indicating the presence of this activity is somewhat higher than 3 , and thus suggests that strategic planning is not entirely underdeveloped in the business practice of Serbian entrepreneurs (Table 2). Nevertheless, given the nature of the scale developed for measuring this variable, the fact that the average score for the level of development of strategic planning activity is 3.37 and that it is significantly different from the test value, it may be concluded that strategic planning is not a fully developed and sophisticated component of the managerial activities of Serbian entrepreneurs. 
Table 2: Development of strategic planning activity in management practice of Serbian entrepreneurs

\begin{tabular}{|c|c|c|c|c|}
\hline $\begin{array}{l}\text { Development of the strategic planning } \\
\text { activity }\end{array}$ & & & \multirow[b]{2}{*}{ Total } & \\
\hline \multirow{2}{*}{ Central tendency measure } & Female & Male & & \\
\hline & 3.35 & 3.38 & 3.37 & \\
\hline \multirow{3}{*}{ One-sample t-test } & \multirow{2}{*}{ Mean } & \multirow{2}{*}{$\begin{array}{l}\text { Standard } \\
\text { deviation }\end{array}$} & \multicolumn{2}{|c|}{ Test value $=3.51$} \\
\hline & & & $\mathbf{t}$ & Sig. \\
\hline & 3.3682 & 0.68126 & -1.944 & 0.039 \\
\hline
\end{tabular}

Analyzing the subcomponents of the strategic planning variable in more detail, some valuable conclusions may be drawn. As results presented in Table 3 show, the planning activity of Serbian entrepreneurs certainly do not result in written plans, while the most pronounced feature of their planning activity is that it is short-term oriented and based on personal experience, feelings and intuition. These results are similar to Welter's (2003) suggesting that strategic decisions in SMEs are often based on the owner's (manager's) experience, intuition or even on guessing (as cited by Kraus et al., 2007). Moreover, scores higher than 4 are assigned only to those sub-components that are exactly the opposite of a well-developed and holistic activity of strategic planning (short time horizon and subjective approach). Once again this supports the claim that strategic planning activity is not performed by Serbian entrepreneurs in all its complexity. Thus, the hypothesis $\mathrm{H} 1$ is confirmed.

Table 3: Implementation of various aspects of planning activity by Serbian entrepreneurs

\begin{tabular}{lrr}
\hline Sub-component & $\begin{array}{c}\text { Mean score } \\
\text { (on 1-5 scale) }\end{array}$ & $\begin{array}{c}\text { Standard } \\
\text { deviation }\end{array}$ \\
\hline I plan for five-years period & 3.05 & 1.35 \\
\hline I plan for one-year period & 4.09 & 1.19 \\
My planning activity results in written plans & 2.74 & 1.32 \\
\cline { 2 - 3 } I plan upon objective data and analysis & 3.56 & 1.20 \\
I plan upon my personal experience, feelings and intuition & 4.04 & 1.12 \\
\cline { 2 - 3 } I plan financial performance & 3.58 & 1.09 \\
\hline I plan production performance & 3.82 & 1.17 \\
\hline I plan marketing performance & 3.76 & 1.05 \\
\hline I define measurable goals & 3.73 & 1.11 \\
\hline
\end{tabular}

Similar to the findings of Stonehouse and Pemberton (2002) and Siddique (2015), results obtained on the Serbian sample suggest that planning activity of entrepreneurs has a short-term horizon. As in the study of Hodges and Kent (2007), most of Serbian entrepreneurs' plans are operational rather than strategic. Moreover, the results support Reiche and Rechke (2005) who analyzed 25 studies and have found that small businesses mostly do not plan sophistically and in a formal way. This does not mean that there is no planning activity, but that it is rather intuitive and informal.

Lerner and Almor (2002) suggest that the age of the business may determine the level to which strategic planning is developed and practiced by its managers. Bracker et al. (1988) even claim that the reason for the results to show that the strategic planning in small businesses is underdeveloped is the fact that a majority of the studies researching this issue use samples constituted out of businesses younger than five years. Due to a short duration of their existence, strategic planning is mostly underdeveloped, which does not have to be the case in older, mature small businesses. However, the results of here presented study challenge this reasoning, because they suggest that the strategic planning activity is underdeveloped in small businesses whose average age is 13.93 years.

The regression model which explains $4.9 \%\left(R^{2}=0.049\right)$ of the profit variability $(F(1.84)=4.31, p=0.041)$ is generated by introducing the mean score representing the level of development of the strategic planning as an independent variable (Table 4). Net profit is getting higher with every additional score for the development of the strategic planning. Thus, the hypothesis $\mathrm{H} 2$ is confirmed. 
Table 4: Simple regression model: Impact of strategic planning on financial performance of Serbian entrepreneurs

\begin{tabular}{l|r|r|r}
\hline \multirow{2}{*}{ Model } & \multicolumn{2}{|c|}{ Unstadardized coefficients } & \multicolumn{2}{c}{ Standardized coefficients } \\
\cline { 2 - 4 } & \multicolumn{1}{c|}{ B } & \multicolumn{1}{c}{ Std. Error } & \multicolumn{1}{c}{ Beta } \\
\hline (Constant) & $-8,001.10$ & $4,965.23$ & $0.221^{*}$ \\
Strategic planning & $2,949.33$ & $1,419.95$ & 2 \\
\hline
\end{tabular}

Note: Values of the net profit are expressed in 000 RSD

The results obtained on the Serbian sample add to the majority of those suggesting a positive relationship between strategic planning and business performance. For example, Carland and Carland (2003), as well as Donkor et al. (2018) find that higher planning intensity leads to better financial performance. Similarly, almost 80 percent of the studies analyzed by Kraus et al. (2006) support the significant positive effect of strategic planning on business performance. Research findings presented by Wijewardena et al. (2004) show that planning sophistication in terms of the existence of formal, written and detailed plans is significantly correlated with higher sale performance of small and medium sized enterprises. Further, based on results of their study, Gomera et al. (2018) conclude that the strategic planning process is of great importance for financial performance of SMEs. Complementing these research works, the current study suggests that small businesses' performance can be enhanced by a planning activity which is formal, covers various functional aspects of the business and which has a long-term focus.

Finally, results do not validate the expectation that there is a gender-based difference regarding the strategic planning activities of entrepreneurs. Although mean scores suggest that this activity is less developed in female entrepreneurs' management practice (3.35 vs. 3.38 , see Table 2 ), the difference is very small and is without statistical significance $(U=1,199.5, p=0.663)$. Moreover, a statistically significant difference between genders was not found regarding any of the sub-components of the planning activity (Table 5).

Table 5: Implementation of various aspects of planning activity by Serbian female and male entrepreneurs

\begin{tabular}{|c|c|c|c|}
\hline \multirow{2}{*}{ Sub-component } & \multicolumn{2}{|c|}{ Mean score (on 1-5 scale) } & \multirow{2}{*}{$\begin{array}{c}\text { Mann-Whitney U } \\
\text { test }\end{array}$} \\
\hline & female & male & \\
\hline I plan for five-years period & 3.03 & 3.06 & $U=1,089 p=0.901$ \\
\hline I plan for one-year period & 4.12 & 4.08 & $U=1,110 p=0.822$ \\
\hline My planning activity results in written plans & 2.76 & 2.74 & $U=1,089 p=0.901$ \\
\hline I plan upon objective data and analysis & 3.33 & 3.68 & $U=1,237 p=0.313$ \\
\hline $\begin{array}{l}\text { I plan upon my personal experience, } \\
\text { feelings and intuition }\end{array}$ & 3.91 & 4.10 & $U=1,206 p=0.606$ \\
\hline I plan financial performance & 3.53 & 3.61 & $U=1,164 p=0.850$ \\
\hline I plan production performance & 3.76 & 3.85 & $U=1,180 p=0.657$ \\
\hline I plan marketing performance & 3.74 & 3.78 & $U=1,179 p=0.760$ \\
\hline I define measurable goals & 3.79 & 3.70 & $U=1,095 p=0.743$ \\
\hline
\end{tabular}

Though unexpected, these results correspond to Perry's (2002) conclusion that gender is not related to planning activity in small businesses. Likewise, Boohene, Sheridan and Kotey (2008) find that in transitional economies, women and men owner-managers of small firms adopt similar approaches to strategic planning. Similarly, Walker et al. (2007) reveal that gender does not play any important role in the likelihood that the entrepreneurs may engage in planning, to have formally written plans, nor in their planning horizons. Building on these notions, the research on Serbian entrepreneurs' planning activity shows that both men and women practice short-term and informal planning, consulting own experience, feelings and intuition rather than deploying objective data and techniques. 
Conclusion

This paper focuses on strategic planning practice of entrepreneurs and reports results of the research into the current state and the importance of strategic planning activity for financial performance of Serbian entrepreneurs. Moreover, it addresses the issue of gender-based difference regarding this managerial activity. The results obtained from the Serbian sample of entrepreneurs confirm the expectation that there is a lack or, at best, low level of strategic planning in their managerial practice. Although covering several functional areas (production, marketing and finance), planning performed by Serbian entrepreneurs is otherwise short-termed, informal and it heavily relies on their personal experience, feelings and intuition instead of on gathered data and comprehensive analysis. Challenging the anticipation, the results show that gender of the entrepreneur is not associated to the level of development of their strategic planning. In other words, strategic planning of both female and male entrepreneurs is unsophisticated, short-termed and informal. At the same time, it was found that the level of development of the strategic planning explains part of the variability in the financial performance of Serbian entrepreneurs contributing to a higher level of profitability. In a word, Serbian entrepreneurs, both men and women without difference, do not practice strategic planning, an activity which has a positive impact on their financial performance. However, it should be noted that these results are obtained on a relatively small sample, so the generalisability of the conclusions may be compromised.

This study aims to contribute to the field of strategic management, and especially to the under researched field of strategic management process performed by entrepreneurs. In a more practical sense, the results of the presented research may direct the development of strategic management and entrepreneurial academic courses and training programmes. Namely, it is evident that Serbian entrepreneurs do not plan strategically. At the same time, those that do perform this activity achieve higher profits. Some scholars suggest that the reasons for not being involved in strategic planning may be the lack of expertise or the entrepreneurs' inadequate knowledge of the process (Gibbons \& O'Connor, 2005; Wang et al., 2007). Moreover, Hodges and Kent (2007) find that small business owners think that their business performance will benefit from more knowledge of this discipline. So, the entrepreneurs should be able to see real tangible effects of the strategic planning in various training programmes which are tailored to their specific needs. Both practical trainings and academic courses should underline the main features of a systematic and sophisticated process of strategic planning; basic techniques and tools of strategic planning should be stressed while the practical implications of strategic planning on entrepreneurial performance should be clearly outlined. Whatever the form in which they are to be organized, education of business students and practitioners should encourage them to plan for a longer term, to set quantitative goals throughout the functional areas of their businesses, to formalize this activity to a certain extent and to do all that by using objective data inputs and analyses.

\section{REFERENCES}

[1] Aidis, R. (2016). Business and occupational crowding: implications for female entrepreneurship development and success. In Diaz-Garzia, C., Brush, C., Gatewood, E., \& Welter, F. (Eds.) Women's Entrepreneurship in Global and Local Contexts (pp. 43-62). Cheltenham (UK), Northampton (USA): Edward Elgar Publishing.

[2] Ali, R. S. (2016). Feminist Theory and Its Influence on Female Entrepreneur's Growth Intentions. Paper presented at the conference: 8th International Scientific ENTRE Conference on Advancing Research in Entrepreneurship in the Global Context (pp. 969-982). Krakow, Poland, 07-08 April, 2016.

[3] Allred, A., Addams, H. L. \& Chakraborty G. (2007). Is Informal Planning the Key to the Success of the INC. 500 ? Journal of Small Business Strategy, 18(1), 95-104.

[4] Amonini C., \& Ogunmokun G.O. (2015). Strategic Marketing Planning Practices: A Study of Australian Small Business Organizations. In: Sidin S., \& Manrai A. (Eds) Proceedings of the 1997 World Marketing Congress. Developments in Marketing Science: Proceedings of the Academy of Marketing Science. Springer, Cham

[5] Arasa, R. \& K'obonyo, P. (2012). The relationship between strategic planning and firm performance. International Journal of Humanities and Social Science, 2(22), 201-213.

[6] Babovic, M. (2012). Pilot study on women entrepreneurship in Serbia (c). Beograd: Program Ujedinjenih nacija za razvoj.

[7] Bird, S., \& Sapp, S. (2004). Understanding the Gender Gap in Small Business Success: Urban and Rural Comparisons. Gender and Society, 18(1), 5-28. DOI: 10.1177/0891243203259129

[8] Boohene, R., Sheridan, A., \& Kotey, B. (2008). Gender, personal values, strategies and small businesses performance: A Ghanaian case study. Equal Opportunities International, 27(3), 237-257. DOI: 10.1108/02610150810860075

[9] Braches, B., \& Elliott, C. (2017). Articulating the entrepreneurship career: A study of German women entrepreneurs. International Small Business Journal: Researching Entrepreneurship, 35(3), 535-557. DOI: $10.1177 \% 2 F 0266242616651921$ 
[10] Bracker, J., \& Pearson, J. (1986). Planning and Financial Performance of Small, Mature Firms. Strategic Management Journal, 7(6), 503-522. DOI: 10.1002/smj.4250070603

[11] Bracker, J., Keats, B., \& Pearson, J. (1988). Planning and Financial Performance among Small Firms in a Growth Industry. Strategic Management Journal, 9(6), 591-603. DOI: 10.1002/smj.4250090606

[12] Brinckmann, J., Dew, N., Read, S., Mayer-Haug, K., \& Grichnik, D. (2018). Of those who plan: A metaanalysis of the relationship between human capital and business planning. Long Range Planning, 52(2): 173-188. DOI: 10.1016/j.Irp.2018.01.003

[13] Brinckmann, J., \& Min Kim, S. (2015). Why we plan: The impact of nascent entrepreneurs' cognitive characteristics and human capital of business planning. Strategic Entrepreneurship Journal, 9(2), 153166. DOI: $10.1002 /$ sej. 1197

[14] Carland, J., \& Carland J. (2003). A Model of Entrepreneurial Planning and Its Effect on Performance. Journal of Business and Entrepreneurship, 15(1), 1-20.

[15] Costin, Y. (2012). In pursuit of growth: an insight into the experience of female entrepreneurs. International Journal of Gender and Entrepreneurship, 4(2), 108-127. DOI: 10.1108/17566261211234634

[16] Cuba, R., Denezo, D., \& Anish, A. (1983). Management Practices of Successful Female Business Owners. American Journal of Small Business, 8(2), 40-46. DOI: 10.1177/104225878300800208

[17] Davis, A., \& Olson, E. (2008). Critical competitive strategy issues every entrepreneur should consider before going to business. Business Horizons, 51(3), 211-221. DOI: 10.1016/j.bushor.2008.01.010

[18] Dibrell, C., Craig, J. B., \& Neubaum, D. O. (2014). Linking the formal strategic planning process, planning flexibility, and innovativeness to firm performance. Journal of Business Research, 67(9), 2000-2007. DOI: 10.1016/j.jbusres.2013.10.011

[19] Donkor, J., Donkor, G., \& Kwarteng, C. (2018). Strategic planning and performance of SMEs in Ghana. Asia Pacific Journal of Innovation and Entrepreneurship, 12(1), 62-76. DOI: 10.1108/APJIE-10-2017-0035

[20] Fleck, E., Hegarty, C., \& Neergaard, H. (2011). The politics of gendered growth. International Journal of Gender and Entrepreneurship, 3(2), 164-173. DOI: 10.1108/17566261111140224

[21] Fossen, R., Rothstein, H., \& Korn, H. (2006). Thirty-five years of strategic planning and firm performance research: a meta-analysis. Academy of Management Annual Meeting Proceedings, 2006, 1-112. DOI: 10.5465/ambpp.2006.22896796

[22] Frost, F. (2003). The use of strategic tools by small and medium-sized enterprises: an Australasian study. Strategic Change, 12(1), 49-62. DOI: 10.1002/jsc.607

[23] Gibbons, P., \& O'Connor, T. (2005). Influences on Strategic Planning Processes among Irish SMEs. Journal of Small Business Management, 43(2), 170-186. DOI: 10.1111/j.1540-627x.2005.00132.x

[24] Gibson, B., \& Cassar, G. (2005). Longitudinal Analysis of Relationships between Planning and Performance in Small Firms. Small Business Economics, 25(3), 207-222. DOI: 10.1007/s11187-003-6458-4

[25] Gomera, S., Chinyamurindi, W. T., \& Mishi, S. (2018). Relationship between strategic planning and financial performance: The case of small, micro- and medium-scale businesses in the Buffalo City Metropolitan. South African Journal of Economic and Management Sciences, 21(1), 1-9. DOI: 10.4102/sajems.v21i1.1634

[26] Hagen, B., Zucchella, A., Cerchiello, P., \& De Giovanni, N. (2012). International strategy and performance - Clustering strategic types of SMEs. International Business Review. 21(3), 369-382. DOI: 10.1016/j.ibusrev.2011.04.002

[27] Henry, C., Orser, B., Coleman, S., \& Foss, L. (2017). Women's entrepreneurship policy: a 13 nation cross-country comparison. International Journal of Gender and Entrepreneurship, 9(3), 206-228. DOI: 10.1108/IJGE-07-2017-0036

[28] Hodges, E. H. \& Kent, W. T. (2007). Impact of Planning and Control Sophistication in Small Business. Journal of Small Business Strategy, 17(2), 75-87. DOI:10.1504/IJEIM.2008.022311

[29] Hughes, K., (2005). Female Enterprise in the New Economy. Toronto: University of Toronto Press.

[30] Jorissen A., Reheul, A-M., Laveren, E., \& Martens, R. (2009). Short-term Planning Sophistication in SMEs: The Relationship with Strategy and Perceived Environmental Uncertainty. In Fink, M., \& Kraus, S. (Eds.) The Management of Small and Medium Enterprises (pp. 20-37). New York: Routledge.

[31] Karami, A. (2007). Strategy Formulation in Entrepreneurial Firms. Hampshire: Ashgate Publishing Limited.

[32] Kepler, E. \& Shane, S. (2007). Are Male and Female Entrepreneurs Really that Different? Office of Advocacy, US Small Business Administration, Washington, DC.

[33] Klacmer Calopa, M. (2017). Business owner and manager's attitude towards financial decision-making and strategic planning: Evidence from Croatian SMEs. Management - Journal of Contemporary Management Issues, 22(1), 103-116. DOI: 10.30924/mjcmi/2017.22.1.103

[34] Kot, S., Meyer, N., Broniszewska, A. (2016). A Cross-Country Comparasion of the Characteristics of Polish and South African Women Entrepreneurs. Recent Issues in Sociological Research, 9(4), 207221. DOI: $10.14254 / 2071-789 X .2016 / 9-4 / 13$ 
[35] Kraus, S., Harms, R., \& Schwarz, E. (2006). Strategic planning in smaller enterprises - new empirical findings. Management Research News, 29(6), 334-344. DOI: 10.1108/01409170610683851

[36] Kraus, S., Reiche, S., Reschke, C. H. (2007). Implications of strategic planning in smes for international entrepreneurship research and practice. In Terziovski, M. (Ed.). Energizing Management through Innovation and Entrepreneurship: European Research and Practice (pp. 110-127). London: Routledge.

[37] Lerner, M., \& Almor, T. (2002). Relationships among Strategic Capabilities and the Performance of Women-Owned Small Ventures. Journal of Small Business Management, 40(2), 109-125. DOI: 10.1111/1540-627X.00044

[38] Lim, S., \& Envick, B. (2013). Gender and entrepreneurial orientation: a multi-country study. International Entrepreneurship and Management Journal, 9(3), 465-482. DOI: 10.1007/s11365-011-0183-2

[39] Löfving, M., Säfsten, K., \& Winroth, M. (2014). Manufacturing strategy frameworks suitable for SMEs. Journal of Manufacturing Technology Management. 25(1), 7-26. DOI: 10.1108/JMTM-08-2012-0081

[40] McKiernan, P., \& Morris, C. (1994). Strategic Planning and Financial Performance in UK SMEs: Does Formality Matter? British Journal of Management, 5(Special Issue), S31-S41. DOI: 10.1111/j.14678551.1994.tb00128.x

[41] Mitchelmore, S., \& Rowley, J. (2013). Growth and planning strategies within women-led SMEs. Management Decision, 51(1), 83-96. DOI: 10.1108/00251741311291328

[42] Mukhtar, S-M. (2002). Differences in Male and Female Management Characteristics: A Study of OwnerManager Businesses. Small Business Economics, 18(4), 289-311. DOI: 10.1023/A:1015235402335

[43] National Agency for Regional Development (2013). State, needs and problems of entrepreneurs in Serbia in 2013 (Stanje, potrebe i problemi preduzetnika u Srbiji u 2013. godini), Belgrade.

[44] Nir, A. (1999). Time Perspectives of Strategic Planning Processes and Plans as a Function of Gender and Echelon Socialization. Sex Roles, 41(9/10), 737-752. DOI: 10.1023/A:1018820126896

[45] Nowinski, W., Haddoud, M. Y., Lancaric, D., Egerova, D., \& Czegledi, S. (2019). The impact of entrepreneurship education, entrepreneurial self-efficacy and gender on entrepreneurial intentions of university students in the Visegrad countries. Studies in Higher Education, 44(2), 361-379. DOI: 10.1080/03075079.2017.1365359

[46] Orser, J., Hogarth-Scott, S. \& Riding, A. (2000). Performance, firm size and management problem solving. Journal of Small Business Management, 38(4),42-58.

[47] Parnell, J., Long, Z., \& Lester, D. (2015). Competitive strategy, capabilities and uncertainty in small and medium sized enterprises (SMEs) in China and the United States. Management Decision. 53(2), 402431. DOI: 10.1108/MD-04-2014-0222

[48] Pasanen, M. (2003). In Search of Factors Affecting SME Performance: The Case of Eastern Finland. Kupio: Kupio University Publications.

[49] Perry, S. (2002). A comparison of failed and non-failed small businesses in the United States: Do men and women use different planning and decision-making strategies? Journal of Developmental Entrepreneurship, 7(4), 415-428.

[50] Reichborn-Kjennerud, K., \& Svare, H. (2014). Entrepreneurial growth strategies: the female touch. Interntational Journal of Gender and Entrepreneuruship, 6(2), 182-199. DOI: 10.1108/IJGE-04-2013-0043

[51] Reiche, S., \& Reschke, C. H. (2005). The Role of Strategic Planning in SMEs: Literature Review and Implications. Paper presented at the conference: British Academy of Management conference British Academy of Management conference, January 2005.

[52] Rue, L., \& Ibrahim, N. (1998). The Relationship between Planning Sophistication and Performance in Small Businesses. Journal of Small Business Management, 36(4), 24-32.

[53] Schayek, R., \& Dvir, D. (2011). The impact of public assistance programs on small businesses: strategic planning, entrepreneurship resources usage, and market orientation as mediating variables. Journal of Small Business Strategy, 22(1), 67-97.

[54] Siddique, M. (2015). A Comparative Study of Strategic Planning Practices of SMEs and Large-Sized Business Organizations in Emerging Economies: The Case of UAE. Strategic Change - Briefings in Entrepreneurial Finance, 24(6), 553-567. DOI: 10.1002/jsc.2039

[55] Spangoli, P., Caetano, A., \& Santos, S. C. (2015). Entrepreneurial self-efficacy in Italy: An Empirical study from a gender perspective. Testing Psychometrics Methodology in Applied Psychology, 22(4), 485-506. DOI: 10.4473/TPM22.4.4

[56] Stonehouse, G., \& Pemberton, J. (2002). Strategic planning in SMEs - some empirical findings. Management Decision, 40(9), 853-861. DOI: 10.1108/00251740210441072

[57] Stosic Panic, D. (2017). Differences in the Human Capital of Female and Male Entrepreneurs - Evidence from the Republic of Serbia. Journal of East European Management Studies, 22(4), 511-539. DOI: 10.5771/0949-6181-2017-4-511

[58] Terjesen, S. (2016). Conditions for high-potential female entrepreneurship. IZA World of Labor. 
[59] Verheul, I., Thurik, R., Grilo, I., \& van der Zwan, P. (2012). Explaining preferences and actual involvement in self-employment: Gender and the entrepreneurial personality. Journal of Economic Psychology, 33(2), 325-341. DOI: 10.1016/j.joep.2011.02.009

[60] Walker, E., Wang, C., \& Redmond, J. (2007). Gender Differences in Small Business Strategic Planning: Do Women Plan More Than Men? Paper presented at the Inaugural International Women and Leadership Conference. (pp. 354-369). Fremantle. Curtin University of Technology. Retrieved from: https://www.google.com/url?sa $=t \& r c t=j \& q=\& e s r c=s \&$ source $=$ web\&cd $=2 \& v e d=0$ ahUKEwigquavrzcAhWhsKQKHQFSA7QQFgg2MAE\&url=https\%3A\%2F\%2Fresearchoutput.csu.edu.au\%2Ffiles\% 2F9708513\%2FPID29953postpub.pdf\&usg=AOvVaw2SLy5g5SLE-0UuU3ELy0sx

[61] Wang, C., Walker, E., \& Redmond, J. (2007). Explaining the Lack of Strategic Planning in SMEs: The Importance of Owner Motivation. International Journal of Organisational Behaviour, 12(1), 1-16.

[62] Welter, F. (2003) Strategien, KMU und Umfeld - Handlungsmuster und Strategiegenese in kleinen und mittleren Unternehmen. Berlin: Duncker \& Humblot.

[63] Wijewardena, H., De Zoysa, A., Fonseka, T., \& Perera, B. (2004). The Impact of Planning and Control Sophistication on Performance of Small and Medium-sized Enterprises: Evidence from Sri Lanka. Journal of Small Business Management, 42(2), 209-17. DOI: 10.1111/j.1540-627X.2004.00106.X

[64] Yusuf, A., \& Saffu, K (2005). Planning and performance of small and medium enterprise operators in a country in transition. Journal of Small Business Management, 43(4), 480-497. DOI: 10.1111/j.1540627X.2005.00148.x

Received: 2018-07-31

Revisions requested: 2018-11-30

Revised: 2019-06-16 (3 times)

Accepted: 2019-06-23

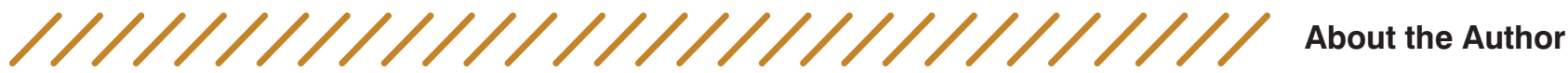

\section{Danijela Stošić Panić \\ University of Niš, Faculty of Economics, Serbia danijela.stosic@eknfak.ni.ac.rs}

Danijela Stošić Panić is an assistant professor for the scientific field of Business Management. Her main research interests lie in strategic management, production management and entrepreneurship. Danijela's research results are presented in over 40 papers published in international and domestic scientific journals. She is an author of one university textbook and a co-author of a monograph. She was a visiting scholar at the Vienna University of Economics and Business and the Karl Franzens University of Graz. As a PhD student she received a national scholarship awarded by the Serbian Ministry of Science and Technological Development. Danijela is and has been involved in numerous domestic and international scientific projects. She is a reviewer in the process of accreditation and quality assurance of higher education institutions in the Republic of Serbia.

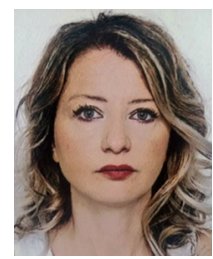

